\title{
Analysis of peripartum hysterectomy at tertiary care hospital in rural Bangalore
}

\author{
Umashankar Km, Sandhya Alletty, Madhushri N, Dharmavijaya Mn \\ Correspondence: Dr Umashankar Km, MVJ Medical College, Department of Obstetrics and \\ Gynaecology, Bangalore. Karnataka; Email - ukumashankar@gmail.com
}

Distributed under Creative Commons Attribution-Share Alike 4.0 International.

\begin{abstract}
Objective: This study was conducted to evaluate the indications and outcomes of emergency peripartum hysterectomy (EPH) as a life-saving procedure. Methods: A series of 60 cases of EPH were analyzed, between June 2006 and June 2016. The data were collected from the patients' files. Results: The incidence of EPH was 3 per 1,000 deliveries. The mean age was $34.10 \pm 6$ years, gravidity was $6.84 \pm 3.38$ and parity was $5.58 \pm 3.0$. Of the 60 cases, 40 were delivered by cesarean section and 20 were vaginally delivered. Forty-five cases had subtotal hysterectomy and 15 had total abdominal hysterectomy. The most common indications for EPH were uterine atony followed by uterine rupture and abnormal placentation. Mean operation time was $142.23 \pm 43.70$ minutes. The average blood transfusion was $4.79 \pm 3.36$ units. Relaparotomy was performed in 22 cases. Maternal mortality was seen in 10 cases. Conclusion: This study suggests that the most common indications for EPH are uterine atony, uterine rupture and abnormal placentation. This is probably due to the advanced age of pregnancies and multiparity in our region.
\end{abstract}

Keywords: Peripartum hysterectomy, uterine atony, caesarian section.

Emergency peripartum hysterectomy is a life-saving surgical procedure, which is performed to control massive hemorrhage. The incidence rate has estimated about 1.5 per 1,000 deliveries in developed countries [1-3]. Cesarean delivery is the major risk factor for peripartum hysterectomy and due to recently raising cesarean delivery rate and the increasing population with a scarred uterus, the incidence of emergency peripartum hysterectomy may indirectly increase. Historically, the most common indication cited for peripartum hysterectomy was uterine atony [4-9]. Emergency peripartum hysterectomy (EPH) is often performed for life-threatening obstetric conditions. It is defined as hysterectomy, performed after cesarean delivery or in the immediate postpartum period. However, EPH may also be performed when a conservative treatment approach fails to arrest postdelivery bleeding. In modern obstetrics, the overall incidences $0.05 \%$, but there are considerable differences in incidence in different parts of the world depending on modern obstetric services, standards and awareness of antenatal care and the effectiveness of family planning activities of a given community [10]. Whiteman ET al [11] reported the incidence in their

Received: $20^{\text {th }}$ September 2016. Accepted: $25^{\text {th }}$ November 2016.

Umashankar Km, Sandhya A, Madhushri N, Dharmavijaya Mn. Analysis of peripartum hysterectomy at tertiary care hospital in rural Bangalore. The New Indian Journal of OBGYN. 2017; 3(2): 95-9 
study as 0.77 per 1,000 births, and Francois et al found the incidence to be 2.28 per 1,000 births [12]. Umezurike et al found that the incidence of EPH was 5.4 per 1,000 deliveries in Aba, southeastern Nigeria [13]. Obstetric hemorrhage continues to be the primary cause of maternal mortality and morbidity in developing countries and the most challenging complication that a clinician will face. In addition, obstetric hemorrhage is a major health problem and contributes to $25 \%$ of direct maternal deaths [14-15]. Indications for peripartum hysterectomy have changed throughout the years. In earlier reports [16-17], the major indications for EPH were uterine rupture and atony, but Sheiner et al [18] listed placenta accrete as the leading cause of peripartum hysterectomy because of a higher rate of cesarean sections. Peripartum hysterectomy is associated with significant morbidity and mortality. The main complications related to emergency peripartum hysterectomy include transfusions [19-21], disseminated intravascular coagulation, infection and potential injury to the adjacent lower urinary tract $[22,23]$ and even maternal death $[6,24]$. Maternal mortality rates reported from $1 \%$ to $6 \%[6,9]$, but some studies in regions with limited medical and hospital resources indicated that this rate is as high as $30 \%$ [24]. In this study, we evaluated the incidence, risk factors, indications, outcomes, mortalities and complications of EPH cases in our university hospital.

\section{Methods}

This retrospective study was included a series of 60 cases of EPH between June 2006 to June 2016 in the university hospital. The data were collected from the patients' files. Maternal age, gravidity, parity, gestational age, types of delivery, risk factors, indications and outcomes of EPH were collected in structured proforma. Peripartum maternal and fetal complications such as fetal mortality and causes of maternal mortality were evaluated. The surgical procedures, type of anesthesia, the operative complications, operation time, preoperative and postoperative hemoglobin and hematocrit levels, amount of blood transfused and the length of stay (days) at the hospital were evaluated. The main complications included massive hemorrhage, infection, uterine tony, uterine rupture, abnormal placentation, placental abruption, disseminated intravascular coagulopathy, pelviperitonitis and bacterial sepsis. In addition, multiple reoperations, readmissions, maternal and fetal mortality and morbidity were determined. The mean and standard deviation were calculated for continuous variables. Independent-sample $t$ tests evaluated associations between the categorical and continuous variables. Two-sided $p$ values were considered statistically significant at $p<0.05$. Statistical analyses were carried out using the statistical package SPSS version15.0 (SPSS Inc., Chicago, IL, USA) for Windows.

\section{Results}

During a 10-year period, a total of 20,002 of women were delivered; 10,600 (53\%) of them delivered

\begin{tabular}{|l|l|}
\hline \multicolumn{2}{|c|}{$\begin{array}{c}\text { Table 1. Indications for emergency } \\
\text { peripartum hysterectomy in } 60 \text { cases }\end{array}$} \\
\hline Indications & N=60 (\%) \\
\hline Uterine atony & $22(36.6 \%)$ \\
\hline Uterine rupture & $16(9.6 \%)$ \\
\hline Abnormal placentation & $9(5.4 \%)$ \\
\hline $\begin{array}{l}\text { Uterine bleeding secondary to } \\
\text { pelviperitonitis }\end{array}$ & $4(1.35 \%)$ \\
\hline Abruptio placenta & $4(1.35 \%)$ \\
\hline Uterine myoma and bleeding & $1(0.6 \%)$ \\
\hline Vesicouterine rupture & $2(1.2 \%)$ \\
\hline Uterine inversion & $1(0.6 \%)$ \\
\hline Choriocarcinoma and bleeding & $1(0.6 \%)$ \\
\hline
\end{tabular}

vaginally and $9400(47 \%)$ by cesarean section. EPH was performed in a series of 60 cases. The incidence was 3 per 1,000 deliveries. The mean age of cases that underwent EPH was $34.10 \pm 6$ years (range, 21-49 years), gravidity was $6.84 \pm 3.38$ and parity was $5.58 \pm 3.04$. Hysterectomies were performed in 20 $(33.33 \%)$ cases after vaginal birth and $40(66.66 \%)$ cases during cesarean section and relaparotomy due to massive obstetrics hemorrhage. Primary cesarean 
The New Indian Journal of OBGYN. 2017 (January-June); 3(2)

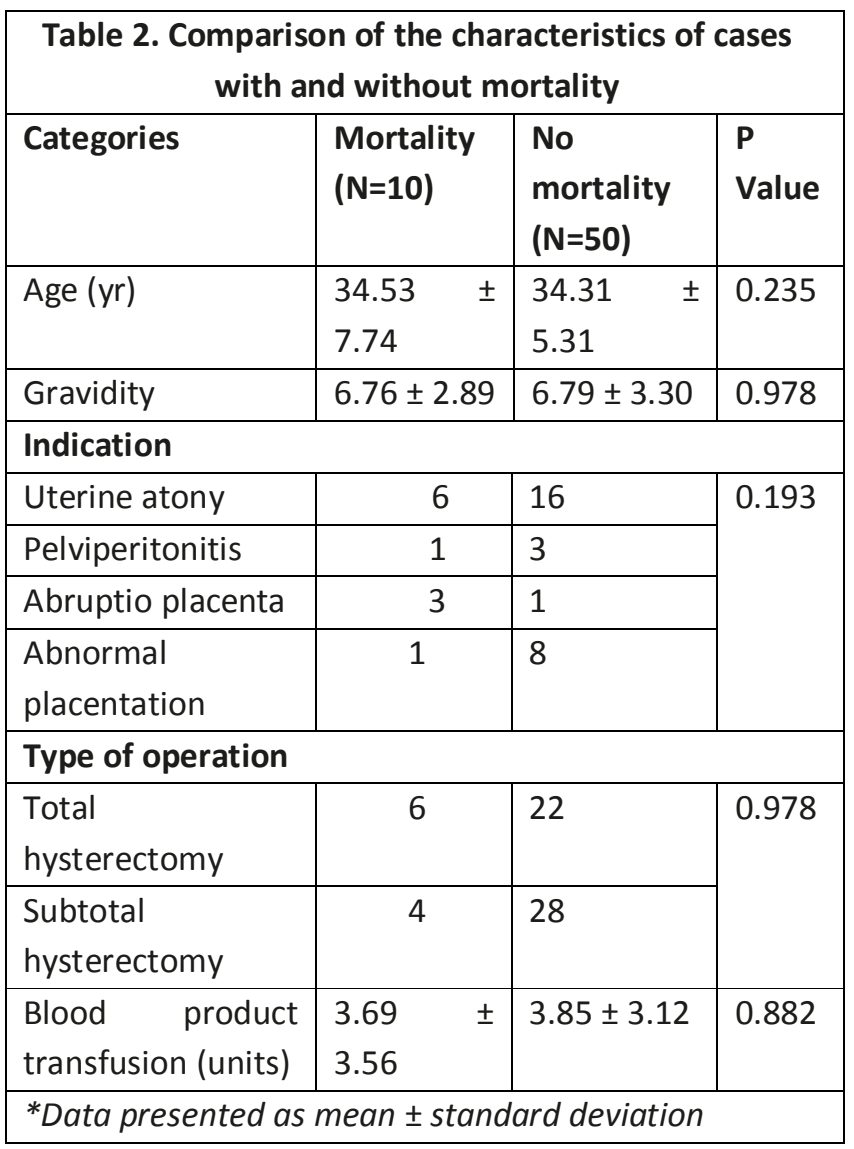

section was found in $10(25 \%)$ cases and previous cesarean section (second or more) in 30(75\%) cases. Subtotal hysterectomy was performed in $45(75 \%)$

\begin{tabular}{|l|l|}
\hline \multicolumn{2}{|l|}{ Table 3. Postoperative morbidities of 60 cases } \\
\hline Morbidites (hemorrhage and & $\mathbf{N}=60(\%)$ \\
\hline $\begin{array}{l}\text { Relaparotomy } \\
\text { others) }\end{array}$ & $12(20 \%)$ \\
\hline Postoperative febrile reaction & $10(16.6 \%)$ \\
\hline Dehiscence and wound infection & $5(8.3 \%)$ \\
\hline Acute renal failure & $2(3.3 \%)$ \\
\hline Bladder injury & $3(5 \%)$ \\
\hline Ureter injury & $3(5 \%)$ \\
\hline ARDS and DIC & $3(5 \%)$ \\
\hline Others & \\
\hline
\end{tabular}

Table 4. Comparison of the characteristics of cases with and without postoperative morbidity

\begin{tabular}{|c|c|c|c|}
\hline Categories & $\begin{array}{l}\text { With } \\
\text { morbidity } \\
\mathrm{N}=25\end{array}$ & $\begin{array}{l}\text { Without } \\
\text { morbidity } \\
\mathrm{N}=35\end{array}$ & \begin{tabular}{|l|}
$P$ \\
value
\end{tabular} \\
\hline Age (yr) & $33.25 \pm 5.75$ & $35.09 \pm 6.12$ & \\
\hline Gravidity & $6.72 \pm 3.37$ & $6.84 \pm 3.18$ & \\
\hline Parity & $5.75 \pm 3.16$ & $5.47 \pm 2.71$ & \\
\hline \multicolumn{4}{|c|}{ Type of hysterectomy } \\
\hline $\begin{array}{l}\text { Subtotal } \\
\text { hysterectomy }\end{array}$ & 21 & 39 & \multirow[t]{2}{*}{0.245} \\
\hline $\begin{array}{l}\text { Total } \\
\text { hysterectomy }\end{array}$ & 29 & 31 & \\
\hline $\begin{array}{l}\text { Blood product } \\
\text { transfusion } \\
\text { (units) }\end{array}$ & $4.25 \pm 4.11$ & $3.53 \pm 3.61$ & 0.273 \\
\hline
\end{tabular}

cases and total abdominal hysterectomy in15 (25\%) cases. The main causes of EPH were uterine atony (34.28\%), uterine rupture (30.71\%), abnormal placentation (16.42\%), pelvic infection and uterine bleeding secondary to infection (7.85\%) (table 1). In the cases who survived, the average preoperative hematocrit and hemoglobin levels were $24.40 \pm 7.42 \%$ $(8-41 \%)$ and $8.15 \pm 2.61 \mathrm{~g} / \mathrm{dL}(3-14 \mathrm{~g} / \mathrm{dL})$, and the postoperative hematocrit and hemoglobin levels were $28.02 \pm 4.69 \%(12-40 \%)$ and $9.44 \pm 1.79 \mathrm{~g} / \mathrm{dL}(4-27$ $\mathrm{g} / \mathrm{dL}$ ) respectively. An average of $4.79 \pm 3.36$ units of blood was transfused. Due to intractable hemorrhage, relaparotomy was performed in $22(16.42 \%)$ cases. Despite all efforts, 9 (15\%) cases died due to massive hemorrhage, except for 1 case of sepsis. Nine of 10 mothers died on the 1st day of birth and their mean age was $32.92 \pm 6.63$ years $(25-47$ years). The clinical characteristics and comparison of these cases with living mothers are shown in table 2. Forty-eight of the cases delivered at outside centers or at home and were referred to our hospital in the intensive care unit after massive obstetrics hemorrhage. Twelve cases delivered at our hospital and 31 fetuses were stillborn. Thirty newborns had low Apgar scores; the mean 1-minute 
score was $5.63 \pm 2.21$ and the mean5-minute score was $7.18 \pm 1.75$. The average length of hospitalization was $9.95 \pm 7.26$ days in surviving cases and $31.50 \pm 62.67$ days in cases who died. The most common causes of maternal morbidity included relaparotomy, postoperative febrile reaction and wound problems (table 3). Table 4 summarizes the clinical characteristics of these cases and compares them with the cases without morbidity.

\section{Discussion}

$\mathrm{EPH}$ is a life-saving procedure when other measures do not succeed in halting peripartum bleeding [15]. The incidence of EPH has declined recently and the indications have been restricted to emergent situations. The incidence of peripartum hysterectomy in the USA is 1-3 per 1,000 deliveries [16], but some studies from other countries have reported remarkably lower rates than the USA [19-21]. In this study, the overall incidence of EPH was 3 per 1,000 deliveries, and this incidence is similar to that of USA incidence.

Tahir et al [22] reported 30 EPH cases, including 2 mothers who died and 2 cases that underwent a repeat laparotomy. In this study, 22 (36.6\%) cases underwent relaparotomy due to intractable bleeding and insufficient previous operations performed at outside centers. These situations indicate that we have an unfavorable health system in our region.

Although uncontrollable hemorrhage and infection were once considered the principal risk factors, abnormal placentation is currently thought to be the major risk factor for peripartum hysterectomy [23-27]. In this study, the most common indications of EPH were uterine atony, uterine rupture, abnormal placentation and pelviperitonitis. Numerous causes might have contributed to our high incidence of hysterectomies, such as lower socioeconomic status, lower income, poverty, lower standards of health care, high parity, religious and traditional habits, delay in arriving at hospital. In addition, our hospital is a tertiary and reference center, and therefore, many cases with complications are referred to our hospital. Unless these tragic problems are resolved with the aid of the government, we believe that the incidence will not decrease.

\section{Conclusion}

In this study, the most common indications of EPH were uterine atony, uterine rupture, abnormal placentation and pelviperitonitis. Relaparotomy, postoperative febrile reaction, dehiscence and wound infection are the common morbidities.

\section{Conflict of interest: None. Disclaimer: Nil.}

\section{References}

1. Forna F, Miles AM, Jamieson DJ. Emergency peripartum hysterectomy: A comparison of cesarean and postpartum hysterectomy. Am J Obstet Gynecol. 2004; 190:1440-4.

2. Whiteman MK, Kuklina E, Hillis SD, Jamieson DJ, Meikle SF, Posner SF, et al. Incidence and determinants of peripartum hysterectomy. Obstet Gynecol. 2006; 108: 1486-92.

3. Zelop CM, Harlow BL, Frigoletto FD Jr, Safon LE, Saltzman DH. Emergency peripartum hysterectomy. Am J Obstet Gynecol. 1993; 168:1443-8.

4. Chestnut DH, Eden RD, Gall SA, Parker RT. Peripartum hysterectomy: A review of cesarean and postpartum hysterectomy. Obstet Gynecol. 1985;65:36570.

5. Clark SL, Yeh SY, Phelan JP, Bruce S, Paul RH. Emergency hysterectomy for obstetric hemorrhage. Obstet Gynecol. 1984;64:376-80.

6. Kwee A, Bots ML, Visser GH, Bruinse HW. Emergency peripartum hysterectomy: A prospective study in the Netherlands. Eur J Obstet Gynecol Reprod Biol. 2006;124:187-92.

7. Langdana F, Geary M, Haw W, Keane D. Peripartum hysterectomy in the 1990s: Any new lessons? J Obstet Gynaecol. 2001; 21:121-3.

8. Stanco LM, Schrimmer DB, Paul RH, Mishell DR Jr. Emergency peripartum hysterectomy and associated risk factors. Am J Obstet Gynecol. 1993;168:879-83.

9. Yucel O, Ozdemir I, Yucel N, Somunkiran A. Emergency peripartum hysterectomy: A 9-year review. Arch Gynecol Obstet. 2006;274:84-7. 
10 Park EH, Sachs BP. Postpartum haemorrhage and other problems of third stage. In: James DK, Steer PJ, Weiner CP, Gonik B, eds. High Risk PregnancyManagement Options, 2nd edition. Philadelphia: W.B. Saunders, 1999:1231-46.

11 Whiteman MK, Kuklina E, Hillis SD, Jamieson DJ, Meikle SF,Posner SF, Marchbanks PA. Incidence and determinants of peripartum hysterectomy. Obstet Gynecol. 2006;108:1486-92.

12. Francois K, Ortiz J, Harris C, Foley MR, Elliott JP. Is peripartum hysterectomy more common in multiple gestations? Obstet Gynecol. 2005;105:1369-72.

13. Umezurike CC, Feyi-Waboso PA, Adisa CA. Peripartum hysterectomy in Aba southeastern Nigeria. Aust N Z J Obstet Gynaecol. 2008; 48:580-2.

14. Yamani Zamzami TY. Indication of emergency peripartum hysterectomy: review of 17 cases. Arch Gynecol Obstet. 2003;268:131-5.

15. Forna F, Miles AM, Jamieson DJ. Emergency peripartum hysterectomy: a comparison of cesarean and postpartum hysterectomy. Am J Obstet Gynecol. 2004;190:1440-4.

16. Chestnut DH, Eden, RD, Gall SA, Parker RT. Peripartum hysterectomy: a review of cesarean and postpartum hysterectomy. Obstet Gynecol. 1985;65:36570.

17. Clark SL, Yeh SY, Phelan JP, Bruce S, Paul RH. Emergency hysterectomy for obstetric haemorrhage. Obstet Gynaecol. 1984; 64:376-80.

18. Engelsen I, Albechtsen S, Iversen O. Peripartum hysterectomy: incidence and maternal morbidity. Acta Obstet Gynecol Scand. 2001;80:409-12.

19. Briery CM, Rose CH, Hudson WT, Lutgendorf MA, Magann EF, Chauhan SP, et al. Planned vs emergent cesarean hysterectomy. Am J Obstet Gynecol. 2007;197:154e1-5.
20. Engelsen IB, Albrechtsen S, Iversen OE. Peripartum hysterectomy-incidence and maternal morbidity. Acta Obstet Gynecol Scand. 2001;80:409-12.

21. Selo-Ojeme DO, Bhattacharjee P, Izuwa-Njoku NF, Kadir RA. Emergency peripartum hysterectomy in a tertiary London hospital. Arch Gynecol Obstet. 2005;271:154-9.

22. Bakshi S, Meyer BA. Indications for and outcomes of emergency peripartum hysterectomy. A five year review. J Reprod Med. 2000;45:733-7.

23. Baskett TF. Emergency obstetric hysterectomy. J Obstet Gynaecol. 2003;23:353-5.

24. Gould DA, Butler-Manuel SA, Turner MJ, Carter PG. Emergency obstetric hysterectomy-an increasing incidence. J Obstet Gynaecol. 1999;19:580-3.

25. Sheiner E, Levy A, Katz M, Mazor M. Identifying risk factors for peripartum cesarean hysterectomy: a population-based study. J Reprod Med. 2003; 48:622-6.

26. Kacmar J, Bhimani L, Boyd M, Shah-Hosseini R, Peipert J. Route of delivery as a risk factor for emergent peripartum hysterectomy: a case-control study. Obstet Gynecol. 2003;102:141-5.

27. Tahir S, Aleem M, Akram S. Indication and maternal outcome of emergency peripartum hysterectomy. Pak J Med Sci. 2003:19; 182-6.

\section{Umashankar $\mathrm{Km}^{1}$, Sandhya Alletty ${ }^{2}$, Madhushri ${ }^{3}$, Dharmavijaya $\mathrm{Mn}^{4}$}

${ }^{1}$ Associate Professor, Department of Obstetrics and Gynaecology, MVJ Medical College, Bangalore, Karnataka, India; ${ }^{2}$ Assistant Professor, Department of Obstetrics and Gynaecology, Maleka Medical College, Udapi, Mangalore, Karnataka; ${ }^{3}$ Resident Doctor, Department of Obstetrics and Gynaecology, MVJ Medical College, Bangalore, Karnataka, India; ${ }^{4}$ Professor and HOD, Department of Obstetrics and Gynaecology, Akash Institute of Medical College, Bangalore, Karnataka, India. 